\title{
SINUSOIDAL OBSTRUCTION SYNDROME (SOS)
}

\author{
${ }^{1}$ Marco Aurelio Salvino, ${ }^{2}$ Roselene Passos, ${ }^{3}$ Luiz Henrique de Assis, ${ }^{4}$ Natalia Maria Borges \\ ${ }^{5}$ Nelson Hamerschlak
}

1 Universidade Federal da Bahia/Hospital São Rafael-BA, 2 Hospital 9 de julho/Hospital de Transplantes Euryclides de Jesus Zerbini, 3 Hospital São Rafael-BA, 4 Hospital São Rafael-BA/Hospital Pediatrico Martagao Gesteira, 5 Hospital Israelita Albert Einstein

\section{INTRODUCTION:}

Hepatic venocclusive disease (VOD), also known as sinusoidal obstruction syndrome (SOS), is a potentially fatal complication that occurs mainly after myeloablative conditioning (MAC) hematopoietic stem cell transplantation (HSCT), but may occur rarely after reduced intensity conditioning (RIC), autologous HSCT, exposure to hepatotoxic chemotherapy outside the context of transplantation or after liver transplantation. It was initially described in patients who ingested marijuana tea containing pyrrolizidine alkaloids, and was first described in 1979. [1]

It is a disease related to hepatic vascular injury, characterized by damage to small vessels, mainly affecting the sinusoidal endothelium, which results in complications such as intrahepatic congestion, liver damage and portal hypertension. SOS was previously called hepatic venocclusive disease, until several studies suggested that the injury of the hepatic sinus endothelium was greater than the injury to the hepatic veins. [2]

It is characterized in clinical grounds by painful hepatomegaly, weight gain and jaundice, although anicteric forms may occur, most commonly in the pediatric population. It may evolve to multiple organ dysfunction (with mortality exceeding $80 \%$ ), pulmonary disorders (pleural effusion, pulmonary infiltrates and hypoxia), renal failure and/or neurological deterioration (confusion and encephalopathy). The incidence is approximately 5 to $13 \%$, even more common in the pediatric group [3] in which can reach $20-30 \%$ up to $60 \%$. It occurs in approximately $10-15 \%$ of allogeneic HSCT with MAC conditioning and less than $5 \%$ of the autologous or RIC conditioning. [4]

\section{PATHOPHYSIOLOGY:}

The basic structural component of the liver is the hepatocytes, which correspond to $80 \%$ of the organ volume and are distributed in liver slides with various functions. Through the hepatocytes flow the biliferous canaliculi, which join distally forming increasingly larger ducts, resulting in the hepatic ducts. Among the hepatocytes plaques pass the hepatic sinusoids, which are fenestrated blood capillaries that receive oxygenated blood from the hepatic artery and nutrient-rich blood from the hepatic portal vein. The normal flow in the portal vein is hepatopetal, that is, directed to the liver.

Between the sinusoids and hepatocytes, we have the Space of Disse, where the microvilli of the hepatocytes extend. Hepatic sinusoids are coated by endotelial cells, whose function is filtration and removal of metabolites.

The initial event in VOD/SOS is endothelial injury of the hepatic sinusoid, with loss of cohesion between the endothelial cells, with extravasation of red blood cells into the Space of Disse, with embolization through centrolobular vein and subsequent postsinusoidal obstruction. [1]

The etiologies of endothelial injury are conditioning regimens (mainly busulfan and cyclophosphamide metabolites), cytokines produced by injured tissues, microbial products resulting from the breaking of the mucosal barrier, drugs used during transplantation (as granulocyte colony-stimulating factors or calcineurin inhibitors), the grafting process and alloreactivity. 
Chemotherapeutic drugs are metabolized by cytochrome P450, producing toxic metabolites that are converted by the glutathione enzymatic system into non-toxic metabolites to later be eliminated. The centrolobular regions of the liver are poor in glutathione and for this reason are more sensitive to the action of toxic agents. The immaturity of this enzymatic system in the pediatric group may explain the higher incidence of SOS in children. The higher incidence after allogeneic HSCT and in unrelated transplants, suggests the participation of alloreactivity in the pathophysiology of VOD/SOS. Activated sinus endotelias (CES) cells increase the production of cytokines, heparanase and expression of adhesion molecules with loss of cytoskeletal structure, space formation that facilitates the extravasation of red blood cells, leukocytes and cellular debris into the Space of Disse, with narrowing of the sinusoids . [5]

The increase in tissue factor and plasminogen activating factor (PAI-1) lead to a procoagulant and hypophybrinolytic state, with consequent fibrin clot formation, narrowing and obstruction of the hepatic sinusoid (Figure 2.C.). [5]

Detachment of endothelial cells seems to be correlated with nitric oxide deficiency caused by post-conditioning toxicity. Nitric oxide deficiency promotes increased production of metalloproteinase matrix 9 , responsible for the detachment of endothelial cells. Obstruction of blood flow is promoted by the proliferation of perisinusoidal star cells and subendothelial fibroblasts in the terminal hepatic vein, followed by the deposition of the extracellular matrix. Then fibrosis extends to the liver parenchyma leading to blockage in the blood output of the liver, leading to hepatic congestion and development of post-sinusoidal portal hypertension. [3]

\section{RISK FACTORS:}

The analysis of risk factors with the identification of subgroup of patients at higher risk for developing severe forms of the disease are necessary for early intervention and prevent the development of multiple organ dysfunction (MOD). [6][7]

There are three types of risk factors: directly related to transplantation; related to the patient or underlying disease; liver-related factors.

\subsection{HSCT RELATED FACTORS:}

-Allogeneic HSCT is at higher risk when compared to autologous HSCT
-Unrelated donor

-Donor with mismatch

-T-cell depletion-without-depletion transplant

-Myeloablative conditioning

-Conditioning regimen with high doses of bussulfan or oral formulation; melphalan; Cyclophosphamide.

-High doses of total body irradiation (TBI)

-Second myeloablative transplant

-Interval between diagnosis and HSCT > 13 months

-Pharmacological Prophylaxis of graft-versus-host disease (GVHD): association of sirolimus, metotrexate and tacrolimus; cyclosporine and metotrexate.

\subsection{FACTORS RELATED TO THE PATIENT OR} THE DISEASE:

- Low age in children and advanced age in adults

-Hepatitis $B / C$ positive serology

-Positive serology for cytomegalovirus

-Low Karnofsky Index (<90\%)

-Metabolic syndrome

-Active disease at HSCT

-High levels of ferritin

-Female women on hormonal contraceptives

-Use of parenteral nutrition up to 30 days before HSCT

-Thalassemia, advanced malignancy, acute leukemia, acute CHS, late platelet grafting

-Genetic factors (GSTM1 polymorphism, C282Y hemochromatosisallallery, MTHFR 677CC/1298CC haplotype)

\subsection{LIVER-RELATED FACTORS:}

-Transaminases above 2.5 times normal upper limit

-Bilirubin level above 1.5 times normal upper limit

-Low albumin level

-Active viral hepatitis

-Cirrhosis

-Liver or abdominal irradiation 
-Iron overload (high serum ferritin levels)

-Previous use of gentuzumab ozogamicin [8]

-Hepatotoxic drugs

\subsection{PAEDIATRIC RISK FACTORS:}

-Hemaphagocytic Lymphohistiocytosis

-Adrenoleukodystrophy

-Osteopetrosis

-Neuroblastoma with high doses of chemotherapy

-Age $(<1-2$ years)

-Low weight

-Chronic myelomonocytic leukemia (CMML)

-Juvenil Mielomomonocytic leukemia (JMML)

-Hemoglobinopathies

\subsection{RISK SCORE FOR VOD DEVELOPMENT AFTER ALLOGENEIC HSCT:}

A risk score for the development of SOS/VOD may be useful in identifying high-risk patients to seek preventive strategies for this complication that can be fatal. Recently the Center for International Blood and Marrow Transplant Research (CIBMTR) developed a pre-transplant risk score through the evaluation of 13,097 patients submitted to the first allogeneic HSCT between 2008 and 2013 and prognostic factors for the development of SOS/VOD up to D+100 after transplantation were identified through analysis with multivariate logistic regression model. Variables with significance in the risk score:

-Age (children > adults)

-Performance score (Karnofsky) $<90 \%$

-Use sirolimus

-Hepatitis B/C (positive hepatitis B and C or only Positive B)

-Conditioning regimen (MAC regimen with melphalan, fludarabine, busulfan with serum level monitoring; TBI)
Status pre-HSCT / Underlying disease (bone marrow aplasia, Hodgkin and non-Hodgkin lymphoma, myelodysplastic syndrome, advanced chronic myeloid leukemia, and myeloproliferative syndromes).

The model can be brought into clinical practice with an online risk calculator, accessible to the public via the link below:

\section{https://www.cibmtr.org/ ReferenceCenter/Statis- tical/Tools/Pages/VOD.aspx}

With the use of the tool, patients at high risk for developing SOS/VOD may have a closer follow-up and modifications in the conditioning regimen may be discussed. The identification of high-risk patients may also facilitate early initiation of drug therapy with defibrotide from the first symptoms of SOS/ VOD, which demonstrated improvement in survival of patients who developed the complication. [9]

\section{CLINICAL MANIFESTATIONS:}

They are due to portal hypertension, usually occur during first 21 days of HSCT, but may occur later in 15 to $20 \%$ of cases (21-508 days). It can range from mild clinical manifestations with spontaneous resolution in a few weeks to multiple organ dysfunction (MOD), with high mortality. Given the severity of the condition, daily monitoring of weight, abdominal circumference, diuresis and water balance is necessary for early diagnosis of the complication. [3] [6]

The characteristic clinical manifestations are:

-Weight gain, generally not responsive to diuretics

- Hyperbilirubinemia

- Painful hepatomegaly

-Ascites

The diagnosis of VOD/SOS is classically based on the clinical criteria of modified Baltimore or Seattle, and exclusion of differential diagnoses.

More than $30 \%$ of children and $12 \%$ adults may evolve with SOS/VOD and be anicteric. Therefore, the importance of applying the various diagnostic criteria, since in Baltimore criteria jaundice is mandatory. Therefore, the proposal of the EBMT criteria. [4] 


\begin{tabular}{|c|c|c|}
\hline Modified Seattle Criteria & Baltimore Criteria & EMBT Criteria (6) \\
\hline $\begin{array}{l}\text { Presence in the first } 21 \text { days of } \\
\text { HSCT of } 2 \text { or more criteria: } \\
\text { Bilirubin }>2 \mathrm{mg} / \mathrm{dL} \\
\text { Painful hepatomegaly } \\
\text { Weight gain }>2 \% \text { of baseline }\end{array}$ & $\begin{array}{c}\text { Presence within the first } 21 \text { days of } \\
\text { HSCT } \\
\text { Bilirubin } \geq 2 \mathrm{mg} / \mathrm{dL} \text { and at least } 2 \text { of } \\
\text { the following: } \\
\text { Painful hepatomegaly } \\
\text { Weight gain }>5 \% \\
\text { Ascites }\end{array}$ & $\begin{array}{c}\text { Classic VOD/SOS } \\
\text { Presence within the first } 21 \text { days of HSCT } \\
\text { Bilirubin } \geq 2 \mathrm{mg} / \mathrm{dL} \text { and at least } 2 \text { of the } \\
\text { following } \\
\text { Weight gain }>5 \% \\
\text { Ascites } \\
\text { Painful hepatomegaly } \\
\text { Late VOD/SOS } \\
\text { diagnosis or } \\
\text { Classic SOS after } 21 \text { days or histological } \\
2 \text { or more criteria below (and evidence with } \\
\text { ultrasound) } \\
\text { Bilirubin }>2 \mathrm{mg} / \mathrm{dL} \\
\text { Painful hepatomegaly } \\
\text { Weight gain }>5 \% \\
\text { Ascites }\end{array}$ \\
\hline
\end{tabular}

Children:(10)

\section{Presence of $\mathbf{2}$ or more parameters:}

- Unexplanied refractoriness to platelet transfusion

-Weight gain for 3 consecutive days even with diuretic use or weight gain $>5 \%$ basal weight

- Hepatomegaly (best if confirmed by imaging as US, CT or MRI)

- Ascites (best if confirmed by imaging such as US, CT, or MRI)

- Bilirubin rising above baseline for 3 consecutive days or increase $>2 \mathrm{mg} / \mathrm{dL}$ in $72 \mathrm{~h}$

\section{DIFFERENTIAL DIAGNOSIS:}

-Volume overload

-Constrictive pericarditis

-Drugs causing liver injury and cholestasis

-Sepsis
-Infectious hepatitis

-Parenteral nutrition and biliary complications

-Cholestasis

Graft-versus-host disease

6. SEVERITY DEGREES:

According to EBMT criteria:

Adults(4)(5)

\begin{tabular}{c|c|c|c|c} 
& Mild & Moderate & Severe & Very Severe \\
\hline Onset of symptoms & 7 days & $5-7$ days & $\leq 4$ days & Any time \\
\hline Bilirubin (mg/dL) & $\geq 2$ and $<3$ & $\geq 3<5$ & Double in $48 \mathrm{hs}$ & $>8 \mathrm{x}$ \\
\hline Increase in BT & $\leq 2 \mathrm{x}$ & $>2$ and $\leq 5 \mathrm{x}$ & $>5$ and $\leq 8 \mathrm{x}$ & $\geq 10$ \\
\hline AST/ALT & $<5$ & $\geq 5 \mathrm{a}<10$ & $\geq 5 \mathrm{a}<10$ & $\geq 2 \mathrm{x}$ or multiple organ \\
dysfunction
\end{tabular}


B.Children(10)

\begin{tabular}{|c|c|c|c|c|}
\hline & Mild & Moderate & Severe & Very severe \\
\hline AST/ALT & $\leq 2 x$ & $>2$ and $\leq 5$ & & $>5 x$ \\
\hline $\begin{array}{c}\text { Refractoriness to platelet } \\
\text { transfusion }\end{array}$ & $<3$ days & 3-7days & & $>7$ days \\
\hline Bilirubin (mg/dL) & $<2$ & $<2$ & $<2$ & $>2$ \\
\hline Increase in BT & & & & Double in 48 hs \\
\hline Ascites & Minimal & Moderate & Moderate & Paracentesis \\
\hline Clotting studies & Normal & Normal & Changed & $\begin{array}{c}\text { Need to reset coagulation } \\
\text { factors }\end{array}$ \\
\hline Renal function ( $\mathrm{ml} / \mathrm{min}$ ) & $89-60$ & $59-30$ & $29-15$ & $<15$ \\
\hline $\begin{array}{l}\text { Lung function } \\
\text { (02 need) }\end{array}$ & $<2 \mathrm{~L} / \mathrm{min}$ & $>2 \mathrm{~L} / \mathrm{min}$ & $\mathrm{Vm}$ & $\mathrm{Vm}$ \\
\hline $\begin{array}{c}\text { Central Nervous System } \\
\text { Impairment }\end{array}$ & Out & Out & Out & Cognitive impairment \\
\hline
\end{tabular}

\section{DIAGNOSIS:(3)(3)}

The diagnosis is essentially clinical and based on the clinical criteria of modified Baltimore or Seattle, as previously described. Level of evidence: High and Degree of recommendation: Strong $(1 \mathrm{~A})$

Given the high mortality of severe SOS/VOD (> 80\%), daily monitoring of the patient should be performed from conditioning to at least 14 days after transplantation, especially when the patient presents risk factors; monitor for jaundice, weight gain, positive water balance, ascitis, edemas, hepatomegaly, emphasizing that in the pediatric population it is not uncommon to absence of jaundice.( 12)

-Percutaneous liver biopsy should be avoided due to risk of bleeding; transjugular liver biopsy can minimize the risk of bleeding and enables measurement of hepatic vein pressure.

-Potential Proposed Biomarkers: plasminogen activation inhibitor 1, von Willebrand factor, thrombomodulin, soluble intercellular 1 binding molecule, tumorigenicity suppressor 2 , angiopoietin 2 , hyaluronic acid, interleukin-6, interleukin-10, CD97. (13) Level of evidence: Low and Degree of recommendation: Weak $(2 \mathrm{C})$

-Ultrasonography: many studies report the importance of the test to exclude other diagnoses. Some findings that may be present are hepatomegaly, splenomegaly, vesicle wall thickening $(>6 \mathrm{~mm})$, enlargement of portal vein diameter $>8 \mathrm{~mm}$ in children and $12 \mathrm{~mm}$ in adults, hepatic vein diameter $<3$ $\mathrm{mm}$, ascites and visualization of paraumbilical vein. (11) Level of evidence: Moderate and Degree of recommendation: Weak (2B)

-Doppler ultrasound: approximately $83 \%$ sensitivity and specificity of $87 \%$ in the presence of 6 following criteria:

1.Flow modulation in the portal vein

2.Decrease in density and spectral

3. Hepatofugal flow or maximum speed less than 10 $\mathrm{cm} /$ second

4.Portal vein congestion (inde $\geq 0.1$ )

5.Resistive hepatic artery (index $\geq 0.75$ )

6.Single-phase flow in the hepatic vein

7.Demonstration of flow in the periumbilical vein $-\mathrm{MRI}$

\section{PROPHYLAXIS}

-Iron quelation prior to HSCT

-Avoid use of alcohol and hepatotoxic drugs

- If possible reduced intensity conditioning regimen

-2-day interval between busulfan and cyclophosphamide

-1 day interval between busulfan and melphalan

-Pharmacokinetics study of busulfan 
-Avoid G-CSF: used to accelerate the recovery of neutropenia, but increases the adhering molecules (VCAM- 1 and E-selectin) and can activate endothelial cells. [14]

-Ursodeoxycholic acid: a randomized, double-blind, placebo-controlled study showed a lower incidence of SOS in the group that received ursodeoxycholic acid prophylaxis at a dose of $300 \mathrm{mg}$ twice daily, or $900 \mathrm{mg}$ in patients weighing over $90 \mathrm{~kg}$. [15] It should be initiated before conditioning and maintained up to $d+90$ post HSCT in allogeneic or highrisk autologous HSCT. Level of evidence: Low and Degree of recommendation: weak (2C)

-Defibrotide: there is no strong evidence in adults; only 1 randomized study in the pediatric age group demonstrated a reduction in the incidence of SOS but without benefit in survival. [11]

Children with risk factors: $6.25 \mathrm{mg} / \mathrm{Kg}$ EV 4 times a day. (9) Degree of recommendation $1 \mathrm{~A}$

Adults: $6.25 \mathrm{mg} / \mathrm{Kg} \mathrm{EV} 4$ times a day. (9) Degree of recommendation $2 \mathrm{~B}$

-Heparin: There is no strong evidence for use in adults. Systematic reviews cannot demonstrate benefits in SOS prevention or overall survival for both autologous and allogeneic, possibly due to the great heterogeneity of randomized controlled studies, with variations in the starting of prophylaxis and/or duration. [16] [17] [18]

Degree of recommendation $2 \mathrm{~B}$

\section{MEDICINES USED FOR VOD PROPHYLAXIS[11]}

\begin{tabular}{c|c|c} 
Prophylaxis & Level of evidence & Recommendation \\
\hline $\begin{array}{c}\text { Defibrotide (pediatric population) } \\
\text { Ursodeoxycholic acid (pediatric } \\
\text { population) }\end{array}$ & High & Strong \\
\hline Non Fractionated Heparin & High & Weak \\
\hline Low molecular weight heparin & Low & Weak \\
\hline Ffp & Low & Weak \\
\hline Antithrombin III & Low & Weak \\
\hline PGE 1 (prostaglandin E1) & Low & Weak \\
\hline
\end{tabular}

\section{MAIN STUDIES IN PROPHYLAXIS (EXCEPT GUIDELINES AND EDITORIALS)[19]}

\begin{tabular}{c|c|c|c|c|} 
Author/year & Sos Internship & Type of study & $\begin{array}{c}\text { Patients(defibrotide/ } \\
\text { control)/controle) }\end{array}$ & Dose \\
\hline Corbacioglu,2006 & Not applicable & $\begin{array}{c}\text { Retrospective:cohort/ } \\
\text { historical control }\end{array}$ & $20(9 ; 11)$ children & $40 \mathrm{mg} / \mathrm{Kg} / \mathrm{day}$ EV \\
\hline Quereshi, 2008 & Not applicable & $\begin{array}{c}\text { Prospective: cohort/ } \\
\text { historical control }\end{array}$ & $103(47 ; 56)$ children & $20 \mathrm{mg} / \mathrm{Kg} / \mathrm{day} \mathrm{EV}$ \\
\hline Corbacioglu,2012 & Not applicable & $\begin{array}{c}\text { Prospective, multicenter } \\
\text { randomized }\end{array}$ & $356(180 ; 176)$ children & $\begin{array}{c}6.25 \mathrm{mg} / \mathrm{Kg} / \mathrm{dose} \mathrm{every} \\
6 \mathrm{hs} \mathrm{EV}\end{array}$ \\
\hline Zhang, 2012 & Not applicable & Review & - & $200-400 \mathrm{mg} / \mathrm{day}$ \\
\hline Hopps, 2015 2013 & Not applicable & $\begin{array}{c}\text { Retrospective single } \\
\text { center }\end{array}$ & $49(40$ adults, 9 children $)$ & - \\
\hline Cheuk,2015 & Not applicable & Review & - & - \\
\hline
\end{tabular}




\section{TREATMENT:}

The treatment of VOD / SOS may include supportive and intensive care in addition to specific therapy with defibrotide. Supportive care and clinical monitoring are critical in the management of VOD/SOS throughout the HSCT.

Daily reports of various parameters such as abdominal circumference and weight are recommended in order to promptly capture the clinical diagnosis criteria and to record in a timely manner all dynamic changes and evaluate the responseto treatment and disease progression. [3]

\section{Supportive treatment:}

The basis of supportive treatment in patients with VOD is clinical care, particularly in water balance. The total amount of fluids should be restricted and diuretic therapy instituted. Renal replacement therapy may be required in severe cases. Patients with multiple organ failure will need management in an intensive care environment. Initial discussion with a specialized hepatology unit is advised about other therapeutic options. [15].
In addition to the use of diuretics, ultrafiltration, hemodialysis and water restriction, oxygen support, paracentesis and thoracentesis may also be necessary. It is also recommended to maintain hemoglobin level around $8 \mathrm{~g} / \mathrm{dL}$ and avoid transfusion of incompatible $A B O$ platelets.

2.Defibrotide: $25 \mathrm{mg} / \mathrm{kg} /$ day divided into 4 daily doses for 21 days or until multiple organ dysfunction resolution. Level of evidence: High and Degree of recommendation: Strong $(1 \mathrm{~A})$

Defibrotide is the only drug licensed for treatment of moderate/severe VOD/SOS. It consists of a combination of oligodeoxirribonucleotides derived from the intestinal mucosa of the pig and has antithrombotic, profibrinolytic and anti-inflammatory properties, in addition to the protective effect for the endotelium. [11] [20]

Common adverse reactions are $(>1 \%$ to $<10 \%)$ : intracranial, gastrointestinal, pulmonary, epistaxis, hematuria, bleeding at the catheter site.

\section{MAIN STUDIES WITH DEFIBROTIDE FOR SOS TREATMENT. [19] (EXCEPT GUIDELINES AND EDITORIALS)}

\begin{tabular}{|c|c|c|c|c|}
\hline Author/year & SOS Internship & Type of study & $\begin{array}{l}\text { Patients(defibrotide/ } \\
\text { control)/controle) }\end{array}$ & Dose \\
\hline Haussmann, 2006 & $\begin{array}{l}\text { Severe (10) } \\
\text { Moderate (17) }\end{array}$ & $\begin{array}{c}\text { Prospective/case } \\
\text { series }\end{array}$ & $\begin{array}{c}2 \text { phases: } \\
\text { Prophylaxis SOS: } 71 \text { children, } \\
13 \text { developed SOS } \\
\text { Preemptive antithrombin III } \\
\text { (91 children, } 14 \text { developed } \\
\text { OsOs) }\end{array}$ & $60 \mathrm{mg} /$ day (i.v.) \\
\hline Sucak, 2007 & $\begin{array}{l}\text { Severe (6) } \\
\text { Moderate (4) } \\
\text { Grave (4) }\end{array}$ & $\begin{array}{l}\text { Retrospective/ } \\
\text { single center }\end{array}$ & 14 adults & $\begin{array}{l}\text { Starting dose: } 10 \mathrm{mg} / \mathrm{kg} / \\
\text { day, gradual increase up to } \\
25 \mathrm{mg} / \mathrm{kg} / \text { day }(\mathrm{n}=4) \text { (i.v.). }\end{array}$ \\
\hline Bulley, 2007 & & $\begin{array}{l}\text { Retrospective/ } \\
\text { single center }\end{array}$ & 14 children & $\begin{array}{c}33 \mathrm{mg} / \mathrm{kg} / \text { day at } 38.5 \mathrm{mg} / \\
\mathrm{kg} / \text { day (i.v). }\end{array}$ \\
\hline Ho, 2007 & Review & - & - & - \\
\hline Ho, 2008 & Review & - & - & - \\
\hline Richardson, 2010 & Severe (all patients) & $\begin{array}{l}\text { Phase } 2 \\
\text { (prospective, } \\
\text { randomized, } \\
\text { multicenter) }\end{array}$ & $\begin{array}{l}149(\text { arm } A=75 ; \text { arm } B=74) \\
101 \text { adults and } 49 \text { children }\end{array}$ & \\
\hline Richardson, 2013 & - & Review (security) & - & - \\
\hline
\end{tabular}




\section{CORTICOSTEROIDS:}

Therapy with steroids in high doses may be an option in some cases where defibrotide is not available. The recommended schedule consists of intravenous methylprednisolone $500 \mathrm{mg} / \mathrm{m} 2$ per dose every 12 hours for six doses, followed by a gradual reduction to $2 \mathrm{mg} / \mathrm{kg} / \mathrm{day}$ for 3 days, and subsequently decrease according to the preference of the attending physician (21)

Level of evidence: Low and Degree of recommendation: Weak (2C)

\section{REFERENCES:}

1.Jh Dalle, Giralt SA. Hepatic Veno-Occlusive Disease after Hematopoietic Stem Cell Transplantation: Risk Factors and Stratification, Prophylaxis, and Treatment. Biol Blood Marrow Transplant [Internet]. v. 22, n.3, p. 400-9, 2016. Available from: http://dx.doi.org/10.1016/j.bbmt.

2.Zhang $Y$, Jiang HY, Wei $Y$, Song B. Sinusoidal obstruction syndrome: A systematic review of etiologies, clinical symptoms, and magnetic resonance imaging features. World J Clin Cases. v7, n. 18, p. 2746-59, 2019.

3.Bonifazi F, Barbato F, Ravaioli F, Sessa M, Defrancesco I, Arpinati $M$, et al. Diagnosis and Treatment of VOD/SOS After Allogeneic Hematopoietic Stem Cell Transplantation. Front Immunol. p. 1-13, 11 april 2020.

4.Mohty M, Malard F, Abecassis M, Aerts E, Alaskar AS, Aljurf $M$, et al. Revised diagnosis and severity criteria for sinusoidal obstruction syndrome/ veno-occlusive disease in adult patients: A new classification from the European Society for Blood and Transplantation Marrow. Bone Marrow Transplant [Internet]. v.51, n.7, p. 906-12, 2016. Available from: http://dx.doi.org/10.1038/ bmt..v. 51, n.7, p. 2016.

5.Scala C, Leone Roberti Maggiore U, Remorgida V, Venturini PL, Ferrero S. Drug safety evaluation of desogestrel. Expert Opin Drug Saf. v. 12, n.3, p. 433-44, 2013.

6.Mohty M, Malard F, Abecassis M, Aerts E, Alaskar AS, Aljurf $M$, et al. Revised diagnosis and sever-

\section{ASCITIC FLUID DRAINAGE WITH PERITONEAL DIALYSIS CATHETER:}

Use of a peritoneal dialysis catheter for intraabdominal fluid removal, in children with severe VOD followed by intravascular fluid administration to preserve perfusion and renal function, preventing MOD. [22]

Level of evidence: Very low and Degree of recommendation: Weak (2D)

\section{TRANSJUGULAR INTRAHEPATIC PORTOSYSTEMIC SHUNT (TIPS):}

Has been reported in a few case series.

Level of evidence: Very low and Degree of recommendation: Weak (2D)

ity criteria for sinusoidal obstruction syndrome/ veno-occlusive disease in adult patients: A new classification from the European Society for Blood and Transplantation Marrow. Bone Marrow Transplant [Internet]. v. 51, n.7, p. 906-12, 2016. Available from: http://dx.doi.org/10.1038/ bmt.v.51, n.7, p. 2016.

7.7th Cheuk DK. Hepatic veno-occlusive disease after hematopoietic stem cell transplantation: Prophylaxis and treatment controversies. World J Transplant. v.2, n.2, p. 27, 2012.

8.Richardson PG, Corbacioglu S. Veno-occlusive disease/sinusoidal obstruction syndrome in patients with prior gemtuzumab ozogamicin: literature analysis of survival after defibrotide treatment. Blood Cancer J [Internet]. v.10, n.3, 2020. Available from: http://dx.doi.org/10.1038/ s41408-020-0286-5

9.Strouse C, Zhang Y, Zhang MJ, DiGilio A, Pasquini $M$, Horowitz $M M$, et al. Risk Score for the Development of Veno-Occlusive Disease after Allogeneic Hematopoietic Cell Transplant. Biol Blood Marrow Transplant [Internet]. v. 24, n. 10. p. 2072-80, 2018. Available from: https://doi. org/10.1016/j.bbmt.2018.06.013

10.Kammersgaard MB, Kielsen K, Heilmann C, Ifversen $M$, Müller K. Assessment of the proposed EBMT pediatric criteria for diagnosis and severity grading of sinusoidal obstruction syndrome. Bone Marrow Transplant [Internet]. v.54, n.9, p. 1406-18, 2019. Available from: http://dx.doi. org/10.1038/s41409-018-0426-8 
11.Bajwa RPS, Mahadeo KM, Taragin BH, Dvorak CC, J McArthur, Jeyapalan A, et al. Consensus Report by Pediatric Acute Lung Injury and Sepsis Investigators and Pediatric Blood and Marrow Consortium Transplantation Joint Working Committees: Supportive Care Guidelines for Management of Veno-Occlusive Disease in Children and Adolescents, P. Biol Blood Marrow Transplant [Internet]. v.23, n.11, p. 1817-25, 2017. Available from: https://doi.org/10.1016/j. bbmt.2017.07.021

12.Mohty M, Malard F, Abecassis M, Aerts E, Alaskar AS, Aljurf $M$, et al. Sinusoidal obstruction syndrome/veno-occlusive disease: Current situation and perspectives - A position statement from the European Society for Blood and Marrow Transplantation (EBMT). Bone Marrow Transplant [Internet]. v.50, n.6, p. 781-9, 2015. Available from: http://dx.doi.org/10.1038/bmt.2015.52

13.MA Gillentine, LN Berry, RP Goin-Kochel, MA Ali, J Ge, D Guffey, JA Rosenfeld, V Hannig, P Bader, M Proud, M Shinawi, BH Graham1, A Lin, SR Lalani, J Reynolds, M Chen, T Grebe, CG Minard, P Stankiewicz, AL Beaudet and C, Schaaf. HHS Public Access. J Autism Dev Disord. v.47, n.3, p. 549-62, 2017.

14.Vion AC, Rautou PE, Durand F, Boulanger CM, Valla DC. Interplay of Inflammation and Endothelial Dysfunction in Bone Marrow Transplantation: Focus on Hepatic Veno-Occlusive Disease. Semin Thromb Hemost. v.41, n.6, p. 629-43, 2015.

15.Dignan FL, Wynn RF, Hadzic N, Karani J, Quaglia A, Pagliuca A, et al. BCSH/BSBMT guideline: Diagnosis and management of veno-occlusive disease (sinusoidal obstruction syndrome) following haematopoietic stem cell transplantation. $\mathrm{Br}$ J Haematol. v.163, n.4, p. 1-4, 2013.

16.Marsa-Vila L, Gorin NC, Laporte JP, Labopin M, Dupuy-Montbrun MC, Fouillard L, et al. Prophylactic heparin does not prevent liver veno- occlusive disease following autologous bone marrow transplantation. Eur J Haematol. v. 47, n.5, 1991.

17.Attal $M$, Huguet $F$, Rubie $H$, Huynh A, Charlet $J P$, Payen JL, et al. Prevention of hepatic veno-occlusive disease after bone marrow transplantation by continuous infusion of low-dose heparin: A prospective, randomized trial. Blood, blood. v.79, n.11, p. 2834-40, 1992.

18.Imran H, Im Tleyjeh, Zirakzadeh A, Rodriguez V, Khan SP. Use of prophylactic anticoagulation and the risk of hepatic veno-occlusive disease in patients undergoing hematopoietic stem cell transplantation: A systematic review and meta-analysis. Bone Marrow Transplant. v.37, n.7, p. 677-86, 2006.

19.Steelandt J, Bocquet F, Cordonnier AL, De Courtivron C, Fusier I, Paubel P. Defibrotide in Severe Sinusoidal Obstruction Syndrome: Medicine and Economic Issues. Biol Blood Marrow Transplant [Internet]. 2017;23(2):347-56. Available from: http://dx.doi.org/10.1016/j.bbmt. v.23, n.2, v. 23, n.2, p. 347-56. 2016.

20.Richardson PG, Carreras E, lacobelli M, Nejadnik $B$. The use of defibrotide in blood and marrow. Blood Adv. v.2, n.12, p. 1495-509, 2018.

21.Gloude NJ, Jodele S, Teusink-Cross A, Grimley M, Davies SM, Lane A, et al. Combination of HighDose Methylprednisolone and Defibrotide for Veno-Occlusive Disease in Pediatric Hematopoietic Stem Cell Transplant Recipients. Biol Blood Marrow Transplant [Internet]. v.24, n.1, p. 91-5, 2018. Available from: https://doi.org/10.1016/j. bbmt.2017.09.007

22.Parmar V, Lewis M, Shenoy M, Bonney D, Wynn R. Ascitic fluid drainage using a peritoneal dialysis catheter to prevent and treat multi-organ dysfunction in veno-occlusive disease in children undergoing hematopoietic stem cell transplantation. Pediatr Blood Cancer. v. 64, n.9, p. 1-4, 2017. 